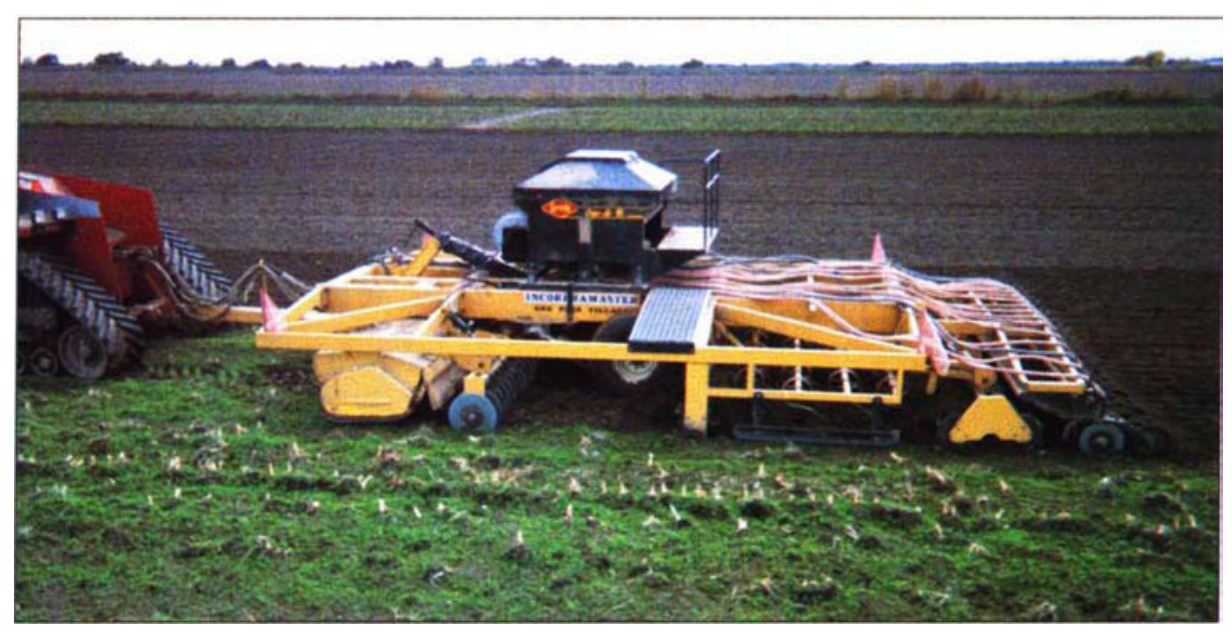

Fuel savings with a new one-pass tillage machine, above, were an average of $50 \%$ better than with the conventional method tested. Time savings ranged from $67 \%$ to $83 \%$, and soil aggregate sizes after tillage did not differ.

\title{
One-pass tillage equipment outstrips conventional tillage method
}

\author{
Shrinivasa K. Upadhyaya $\sqcup$ Kleber P. Lancas $\sqcup$ Abilio G. Santos-Filho $\sqcup$ Narendra S. Raghuwanshi
}

\begin{abstract}
For this study, we compared a new one-pass tillage implement called the Incorpramaster with a conventional tillage practice of stubble disking and land planing. Our randomized block experiment on the UC Davis campus evaluated the equipment's energy and time savings. We found that the one-pass tillage equipment (OPTE) outperformed conventional land preparation methods in fuel consumption and speed. Fuel savings ranged from $19 \%$ to $81 \%$ with a mean savings of $50 \%$. Time savings ranged from $67 \%$ to $83 \%$ with mean of $72 \%$. The mean soil particle size created by the onepass tillage implement was comparable to that produced by conventional tillage methods.
\end{abstract}

7 fficient farm management has al$\checkmark$ ways been of prime importance to farmers, but large increases in capital and operating costs in recent years have made it even more important. Farmers must find ways to maximize their net returns so they can operate within existing economic constraints and respond to growing environmental concerns such as water quality and particulate matter emissions. Nearly 13.4 trillion British thermal units (Btu) of energy is expended in tillage operations in California; almost all of this energy is derived from diesel fuel (Torgerson et al. 1987).

Greater farm profits can be achieved through increased returns or decreased costs. Producing higher value crops depends on factors over which growers have little control, such as climate and market demand. Improved varieties, fertilization, irrigation and management have substantially increased production, but these changes occur more slowly. Expanding acreage is one way to increase total profit, but land constraints and market conditions often prohibit this option.

Therefore, reducing costs without changing any other production pa- rameters is an attractive option. Land preparation prior to planting generally requires significant energy inputs, resulting in high operating costs; new techniques to reduce the cost of preparing land could be beneficial to growers.

Incorpramaster, Inc. of Modesto developed the Incorpramaster, a new one-pass tillage implement, which incorporates several important tillage operations into one machine. The machine we tested was a prototype. The manufacturer reports that it should be commercially available in coming months; we are unaware of any other similar equipment on the market.

The manufacturer claims that one or two operations using this device can replace many operations commonly employed with conventional farming methods. In row-crop production in the Sacramento Valley, this typically includes two passes with a stubble disk and two passes with a land plane.

We compared the performance of the Incorpramaster one-pass tillage equipment (OPTE) with that of typical conventional tillage methods, in terms of speed, energy savings and soil compaction. 


\section{Conservation tillage}

Due to growing concerns about the impact of agricultural production on the environment, conservation tillage has increased over the past few decades. Conservation tillage uses new and proven techniques to reduce soil erosion, conserve moisture and soil structure, reduce energy inputs and production costs, improve land use and reduce labor (Rask et al. 1967; McClure et al. 1968). Conservation tillage attempts to reduce primary soil tillage operations such as plowing, ripping, disking and chiseling, and dedicates tractor traffic to zones away from growing crops (Carter 1995). As a result of deliberate reduction in tractor operations, growers may save energy, produce less dust and sequester more carbon into the soil. Uri (1999) reported that the amount of land planted using conservation tillage in the United States increased from $1 \%$ in 1963 to $37 \%$ in 1997.

According to the Conservation Technology Information Center (Towery 1998), conservation tillage can save as much as 225 hours and 1,750 gallons of fuel per year on just 500 agricultural acres. Fewer trips through the field also saves an estimated $\$ 2,500$ in machinery wear. While this enables growers to farm more profitability, the biggest gain may be the cumulative increase in soil organic matter.

Nonetheless, less than $0.3 \%$ of annual row-crop acreage in California's Central Valley is currently farmed using these practices; however, higher energy costs have spurred new interest in conservation tillage among California growers (Mitchell et al. 2000). Conventional crop production requires nine to 11 tillage operations for preplant field preparation at $18 \%$ to $24 \%$ of total production cost (Mitchell et al. 2000). Carter $(1998,1985)$ and Carter et al. (1991) confirmed the potential to eliminate deep tillage and decrease the number of soil preparation operations by as much as $60 \%$. Conservation- or reduced-tillage practices have the potential to reduce energy and labor costs in California agriculture, and in turn total production costs and negative environmental impacts.

TABLE 1. Savings in fuel consumption and timeliness of Incorpramaster one-pass tillage equipment (OPTE) compared with conventional tillage (CT)

\begin{tabular}{|c|c|c|c|c|c|c|c|c|}
\hline \multirow[b]{2}{*}{ Field } & \multicolumn{2}{|c|}{$\begin{array}{l}\text { Fuel consumption/ } \\
\text { unit area }\end{array}$} & \multicolumn{2}{|c|}{$\begin{array}{c}\text { Time/ } \\
\text { unit area }\end{array}$} & \multicolumn{2}{|c|}{$\begin{array}{l}\text { OPTE } \\
\text { savings }\end{array}$} & \multicolumn{2}{|c|}{$\begin{array}{c}\text { No. of } \\
\text { operations }\end{array}$} \\
\hline & CT & OPTE & CT & OPTE & $\begin{array}{l}\text { Fuel } \\
\text { cons. }\end{array}$ & Time & CT & OPTE \\
\hline & $\begin{array}{c}\text { lha } \\
\text { (gal/ac) }\end{array}$ & $\begin{array}{c}\text { Uha } \\
\text { (gal/ac) }\end{array}$ & $\begin{array}{l}\text { hr/ha } \\
\text { (hr/ac) }\end{array}$ & $\begin{array}{l}\text { hr/ha } \\
\text { (hr/ac) }\end{array}$ & $\%$ & $\%$ & & \\
\hline Plant pathology & $\begin{array}{l}40.42 \\
(4.32)\end{array}$ & $\begin{array}{l}19.13 \\
(2.04)\end{array}$ & $\begin{array}{c}0.94 \\
(0.38)\end{array}$ & $\begin{array}{c}0.31 \\
(0.125)\end{array}$ & 52.7 & 66.9 & 4 & 2 \\
\hline Pomology & $\begin{array}{l}32.96 \\
(3.52)\end{array}$ & $\begin{array}{c}6.17 \\
(0.66)\end{array}$ & $\begin{array}{c}0.94 \\
(0.38)\end{array}$ & $\begin{array}{l}0.16 \\
(0.064)\end{array}$ & 81.3 & 83.1 & 4 & 1 \\
\hline Agricultural practices & $\begin{array}{l}27.36 \\
(2.92)\end{array}$ & $\begin{array}{l}22.19 \\
(2.37)\end{array}$ & $\begin{array}{c}0.95 \\
(0.38)\end{array}$ & $\begin{array}{l}0.28 \\
(0.114)\end{array}$ & 18.9 & 70.4 & 4 & 2 \\
\hline Agronomy & $\begin{array}{l}32.94 \\
(3.53)\end{array}$ & $\begin{array}{l}18.01 \\
(1.93)\end{array}$ & $\begin{array}{c}0.94 \\
(0.38)\end{array}$ & $\begin{array}{l}0.30 \\
(0.123)\end{array}$ & 45.3 & 67.8 & 4 & 2 \\
\hline Average & $\begin{array}{l}33.42 \\
(3.57)\end{array}$ & $\begin{array}{l}16.38 \\
(1.75)\end{array}$ & $\begin{array}{l}0.941 \\
(0.38)\end{array}$ & $\begin{array}{c}0.263 \\
(0.107)\end{array}$ & 50.0 & 72.1 & & \\
\hline
\end{tabular}

\section{Field tests at UC Davis}

In 1998, we conducted tests on four experimental fields (plant pathology, pomology, agricultural practices and agronomy) at UC Davis. The soil texture at these four locations was Yolo fine sandy loam, Brentwood silt loam, Yolo loam and Yolo silt loam, respectively. Our attempts to include a Capay clay field, the typical soil farmed in the Sacramento Valley, were not successful; that field lacked adequate soil moisture for our field work. We selected a randomized complete-block experimental design with four blocks, one at each test site.

We divided each block into two plots and randomly assigned one-pass tillage equipment (OPTE) or conventional tillage to each. The plot sizes were 2.3, 2.6, 4.6 and 3.7 acres at the plant pathology, pomology, agricultural practices and agronomy experimental field sites, respectively. All plots were previously tilled to a depth of 18 inches with a subsoiler, a common practice in rowcrop production in this area. We operated the subsoiler at 45 degrees to the length of the plot during the first pass. During the second pass we operated the subsoiler at right angles to the direction of the first pass.

\section{Tillage equipment}

The OPTE is a large machine, 41 feet long and 18 feet wide, and consists of five tillage tool sets from front to back, allowing several operations to take place during each pass on the field (fig. 1).
Dyna drive unit. According to the manufacturer, the dyna drive unit consists of two mechanically linked rollers, with a gear ratio of $1: 3$ between the first and second rolls. The first roll is ground-driven and in turn drives the second unit. The main purpose of this unit is to loosen soil, break clods and mix stubble or pre-emergent fertilizer.

Spiral reels roller. The spiral reels roller is a ground-driven unit, 18 inches in diameter, which chops stubble, breaks clods and mixes soil or pre-emergent fertilizer. This unit is especially important as it prevents long stubble from clogging the following rows of S-tines.

Chisel unit. A chisel unit with four rows of one-half-inch S-tines with 7-inch sweeps provides deep tillage (beyond the normal plowing zone), uniformly mixes soil by eliminating rhizomes, and creates a consistent seedbed.

Rolling harrows. Two rows of 14-inch rolling harrows follow the S-tines. The pressure on these harrows can be easily adjusted for varying soil conditions using hydraulic cylinders. They also break clods and create a level seedbed.

Ring roller. A 9-inch ring roller on a 7.5 -inch tube provides a smooth, finished seedbed. The rings break clods and seal moisture and/or pre-emergent fertilizer. We operated the OPTE using a 385-horsepower, four-wheel-drive John Deere 8870 tractor. The OPTE's tillage depth 
varied from 6 to 8 inches depending on the initial soil moisture.

In the Sacramento Valley, a typical conventional tillage method for row crops consists of two passes with a stubble disk followed by two passes with a land plane. This is a typical tillage system for a row-crop production system in the Sacramento Valley. We used a 180-horsepower John Deere 4840 tractor for disking and planing operations. The stubble disk had an operating width of 12 feet and a depth of 6 to 8 inches. The land plane had an operating width of 16.2 feet and a depth of 1 to 2 inches.

\section{Field measurements}

We measured fuel consumption and forward speed during field tests and subsequently estimated the energy requirements and performance of both treatments. We also obtained data on cone index, soil density and moisture content to quantify the effect of each treatment on soil compaction. (Cone index refers to penetration resistance of the soil, and is measured using an American Society of Agricultural Engineers [ASAE] standard cone $-30^{\circ}$ cone with 0.5 -square-inch base, operated at 72 inches/minute.) We used tillage depth, clod samples and photographs to evaluate the final soil condition.

We designed and fabricated a special device consisting of a fuel pump powered by the tractor battery, two 2-way valves and a graduated plastic tube to determine the exact fuel consumption of each method (fig. 2). In order to measure fuel levels, we parked the tractor at the same location in each field, before and after each test. We measured the amount of fuel needed to return the manometer fuel level to where it was before the test by weighing an external fuel tank.

To determine the average speed of operation, we measured the time required to travel 200 feet along a straight line, 10 times for each treatment. Also, for each tillage treatment we took 10 measurements of cone index values before and after using a hydraulically operated, instrumented cone penetrometer installed on a John Deere 2010 tractor.

In order to determine the aggregate size distribution, we obtained five soil samples in each plot before and after every test. We analyzed these samples using a standard set of 3 -inch, 1-inch, 3/8-inch, No. 4, 10, 20, 60 and 100 sieves and a mechanical shaker to determine the fraction retained on each sieve. We used these fractions to determine the geometric mean diameter of soil aggregates. The procedure used for finding geometric mean diameter was a modification of the method for determining fineness of feed materials reported in ASAE Standard S319. We also took photographs of experimental plots to visually evaluate the final soil condition. However, this technique turned out to be unreliable, as the effect of each treatment extended to the full operating depth rather than just the surface.

Using a volumetric core ring, we took five soil samples in each plot and
TABLE 2. Mean and standard deviation of performance parameters for Incorpramaster one-pass tillage equipment (OPTE) and conventional tillage (CT)

\begin{tabular}{|c|c|c|c|c|c|}
\hline \multirow[b]{2}{*}{ Cases } & \multicolumn{2}{|c|}{ Mean } & \multicolumn{2}{|c|}{ Standard deviation } & \multirow[b]{2}{*}{ P-values } \\
\hline & OPTE & CT & OPTE & CT & \\
\hline Fuel consumption, gal/ac* & 1.75 & 3.57 & 0.75 & 0.57 & 0.035 \\
\hline Timeliness, hr/ac* & 0.11 & 0.38 & 0.03 & 0.00 & 0.000 \\
\hline Initial cone index, psi & 298.90 & 306.20 & 118.81 & 128.29 & 0.841 \\
\hline Final cone index in tilled layer, psi ${ }^{*}$ & 178.78 & 113.63 & 29.07 & 18.22 & 0.048 \\
\hline Final cone index, psi & 455.93 & 405.07 & 119.07 & 182.76 & 0.698 \\
\hline Initial dry bulk density, $\mathrm{gm} / \mathrm{cm}^{3}$ & 1.21 & 1.25 & 0.03 & 0.05 & 0.098 \\
\hline Final dry bulk density, $\mathrm{gm} / \mathrm{cm}^{3}$ & 1.29 & 1.31 & 0.03 & 0.07 & 0.556 \\
\hline Initial moisture content, \% & 4.75 & 4.38 & 0.90 & 0.50 & 0.207 \\
\hline Final moisture content, $\%$ & 5.24 & 5.73 & 1.00 & 1.65 & 0.599 \\
\hline Operating depth, inches & 6.58 & 6.90 & 0.96 & 0.96 & 0.152 \\
\hline Initial particle size, inches & 0.29 & 0.27 & 0.12 & 0.10 & 0.278 \\
\hline Final particle size, inches & 0.15 & 0.17 & 0.03 & 0.01 & 0.135 \\
\hline
\end{tabular}

"Means are significantly different at $5 \%$ significance level.

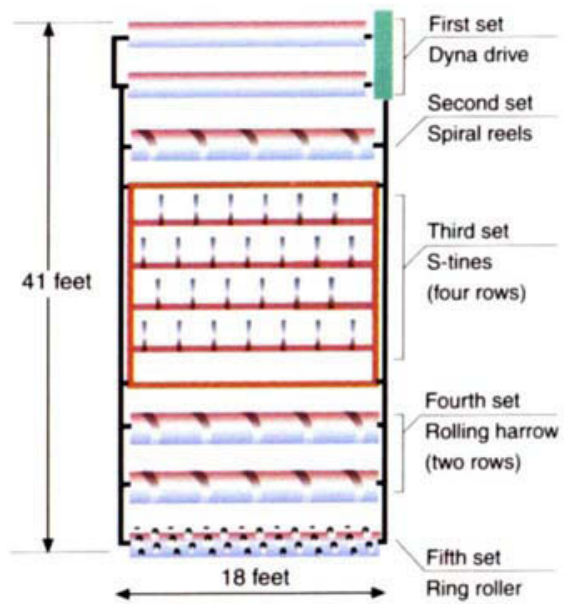

Fig. 1. Schematic diagram of Incorpramaster one-pass tillage equipment.

used the oven-dry method to determine the bulk density and moisture content. Three more core samples were taken after each test to obtain the final bulk-density and moisturecontent data in each plot.

\section{Evaluating the tillage}

Fuel consumption. An analysis of variance (ANOVA) based on a randomized block design showed that the OPTE required a significantly lower amount of fuel (tables 1 and 2). The savings ranged from $19 \%$ to $81 \%$ with a mean of $50 \%$. We attributed the pomology field's higher fuel savings to the fact that only one pass of the OPTE was necessary to create a soil condition comparable to that of the conventional method; two passes of the OPTE were needed in all other test sites.

Speed. We adjusted the time required for stubble disking when the John Deere 8870 tractor was used instead of the John Deere 4840 . The 8870 was used for operating the OPTE, in order to handle its 18-foot stubble disk rather than the 12-foot disk used with the 4840 . The results indicated that the OPTE requires significantly less time compared with the conventional tillage method (tables 1 and 2). The speed advantage for the OPTE ranged from $67 \%$ to $83 \%$ with a mean of $72 \%$.

Cone index values. Mean cone index values did not differ significantly before or after tillage. However, the mean cone index value in the tilled layer was significantly higher for OPTE than conventional tillage 
TABLE 3. Soil and operating conditions for Incorpramaster one-pass tillage equipment (OPTE) and conventional tillage (CT)

\begin{tabular}{|c|c|c|c|c|c|c|c|c|c|c|c|c|c|}
\hline \multirow[b]{2}{*}{ Field } & \multirow[b]{2}{*}{ Tillage system } & \multicolumn{3}{|c|}{ Cone index (CI) } & \multicolumn{2}{|c|}{ Soil moisture } & \multicolumn{2}{|c|}{ Bulk density } & \multicolumn{2}{|c|}{ Particle diameter } & \multicolumn{2}{|c|}{ Forward speed } & \multirow{2}{*}{$\begin{array}{l}\text { Tillage } \\
\text { Depth }\end{array}$} \\
\hline & & Initial & Final & Decrease & Init. & Final & Init. & Final & Init. & Final & Ist & 2nd & \\
\hline & & psi & psi & $\%$ & $\%$ & $\%$ & $\mathrm{gm} / \mathrm{cm}^{3}$ & $\mathrm{gm} / \mathrm{cm}^{3}$ & inches & inches & $\mathrm{km} / \mathrm{hr}$ & $\mathrm{km} / \mathrm{hr}$ & inches \\
\hline $\begin{array}{l}\text { Plant } \\
\text { pathology }\end{array}$ & $\begin{array}{r}\text { CT } \\
\text { OPTE }\end{array}$ & $\begin{array}{l}239.2 \\
189.2\end{array}$ & $\begin{array}{r}98.9 \\
155.2\end{array}$ & $\begin{array}{l}58.7 \\
18.0\end{array}$ & $\begin{array}{l}4.8 \\
5.3\end{array}$ & $\begin{array}{l}8.0 \\
5.0\end{array}$ & $\begin{array}{l}1.3 \\
1.2\end{array}$ & $\begin{array}{l}1.4 \\
1.3\end{array}$ & $\begin{array}{l}0.2 \\
0.2\end{array}$ & $\begin{array}{l}0.2 \\
0.1\end{array}$ & $\begin{array}{r}8.2 \\
11.9\end{array}$ & $\begin{array}{r}8.2 \\
11.6\end{array}$ & $\begin{array}{l}8.3 \\
8.0\end{array}$ \\
\hline Pomology & $\begin{array}{r}\text { CT } \\
\text { OPTE }\end{array}$ & $\begin{array}{l}207.4 \\
207.6\end{array}$ & $\begin{array}{l}139.9 \\
152.1\end{array}$ & $\begin{array}{l}32.5 \\
26.7\end{array}$ & $\begin{array}{l}4.3 \\
4.3\end{array}$ & $\begin{array}{l}5.1 \\
5.5\end{array}$ & $\begin{array}{l}1.2 \\
1.2\end{array}$ & $\begin{array}{l}1.3 \\
1.3\end{array}$ & $\begin{array}{l}0.2 \\
0.2\end{array}$ & $\begin{array}{l}0.2 \\
0.2\end{array}$ & $\begin{array}{r}8.5 \\
11.5\end{array}$ & $\begin{array}{l}7.9 \\
-\end{array}$ & $\begin{array}{l}6.7 \\
5.9\end{array}$ \\
\hline $\begin{array}{l}\text { Agricultural } \\
\text { practices }\end{array}$ & $\begin{array}{r}\text { CT } \\
\text { OPTE }\end{array}$ & $\begin{array}{l}285.7 \\
369.6\end{array}$ & $\begin{array}{l}111.2 \\
202.4\end{array}$ & $\begin{array}{l}61.1 \\
45.2\end{array}$ & $\begin{array}{l}4.7 \\
5.7\end{array}$ & $\begin{array}{l}5.8 \\
6.4\end{array}$ & $\begin{array}{l}1.2 \\
1.2\end{array}$ & $\begin{array}{l}1.3 \\
1.3\end{array}$ & $\begin{array}{l}0.3 \\
0.3\end{array}$ & $\begin{array}{l}0.2 \\
0.1\end{array}$ & $\begin{array}{r}8.2 \\
10.9\end{array}$ & $\begin{array}{r}8.0 \\
15.9\end{array}$ & $\begin{array}{l}6.2 \\
6.2\end{array}$ \\
\hline Agronomy & $\begin{array}{r}\text { CT } \\
\text { OPTE }\end{array}$ & $\begin{array}{l}492.5 \\
429.2\end{array}$ & $\begin{array}{l}104.5 \\
205.4\end{array}$ & $\begin{array}{l}78.8 \\
52.1\end{array}$ & $\begin{array}{l}3.7 \\
3.7\end{array}$ & $\begin{array}{l}4.1 \\
4.0\end{array}$ & $\begin{array}{l}1.2 \\
1.2\end{array}$ & $\begin{array}{l}1.2 \\
1.3\end{array}$ & $\begin{array}{l}0.4 \\
0.5\end{array}$ & $\begin{array}{l}0.2 \\
0.2\end{array}$ & $\begin{array}{r}8.4 \\
10.4\end{array}$ & $\begin{array}{r}8.0 \\
14.1\end{array}$ & $\begin{array}{l}6.4 \\
6.2\end{array}$ \\
\hline Average & CT & 306.2 & 113.6 & 53.2 & 4.4 & 5.7 & 1.3 & 1.3 & 0.3 & 0.2 & 8.3 & 8.0 & 6.9 \\
\hline
\end{tabular}

(table 3). The mean cone index value in the plots tilled by the OPTE was 179 pounds per square inch (psi) compared with 114 psi in conventionally tilled plots. These cone index values were not a concern in the dry soil conditions prevalent during our tests. In wet conditions, however, the pressure in the hydraulic cylinders controlling the rolling harrows of the OPTE may need to be set to lower values.

Density and moisture content. Neither the initial nor the final density or moisture content data significantly differed between the two tillage practices, indicating that the soil condition was uniform to start with and both practices resulted in similar soil conditions after treatment (table 3). A slightly higher moisture content was observed in most of the plots after tillage for both treatments because moist soil from beneath mixed with the dry surface soil.

Operating depth. The ANOVA showed that the operating depth did not significantly differ in the test plots (table 2). Therefore, we felt it was unnecessary to correct fuel consumption values for the respective depths of operation.

Aggregate size analysis. The ANOVA indicated that the mean aggregate size did not differ in the plots before (initial conditions) or after tillage (table 2), demonstrating that both treatments resulted in similar soil conditions.

\section{Time and fuel savings}

Based on our field tests at UC Davis, we found that the one-pass tillage equipment outperformed the conventional land-preparation method of stubble disking and land planing in loamy fields. Fuel energy savings ranged from $19 \%$ to $81 \%$ with a mean savings of $50 \%$. Time savings ranged from $67 \%$ to $83 \%$ with a mean of $72 \%$. Mean aggregate size created by the OPTE was comparable to that produced by the conventional tillage method.

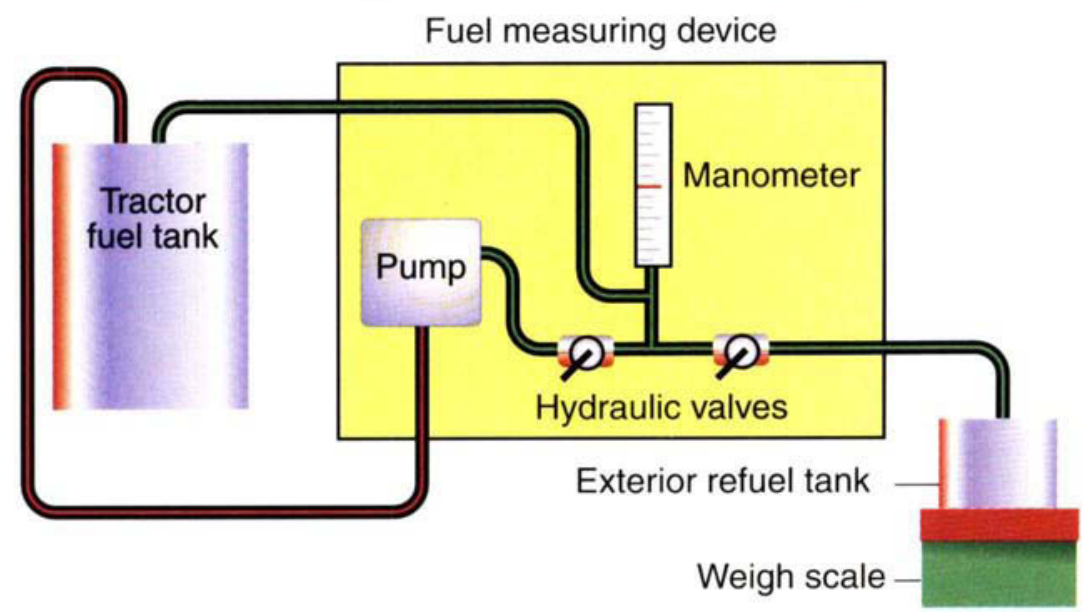

Fig. 2. Schematic of the fuel consumption measurement system used in this study.

S.K. Upadhyaya is Professor, K.P. Lancas is Visiting Professor and A.G. Santos-Filho is Visiting Scholar, Department of Biological and Agricultural Engineering, UC Davis; N.S. Raghuwanshi is Assistant Professor, Agricultural and Food Engineering, Indian Institute of Technology, Kharagpur, India. This study was supported by the Agricultural Energy Assistance Program (Contract No. 400-92-09) of the California Energy Commission. The authors thank Ricado Amon of the California Energy Commission for his interest. The mention of a trade name is not intended as an endorsement of this or similar products by the researchers or $U C$ Davis.

\section{References}

Carter LM. 1985. Wheel traffic is costly. Trans ASAE 28(2):430-4.

Carter LM. 1998. Tillage in Cotton Production. UC DANR Pub P1-14, Oakland, CA. 14 p.

Carter LM, Meek BD, Rechel EA. 1991.

Zone production for cotton: Soil response. Trans ASAE 34(2):354-60.

McClure WR, Phillips SH, Herron JW. 1968. No-tillage experiences in Kentucky. St. Joseph, MI: ASAE Paper No 68-144.

Mitchell JP, Lanini WT, Temple SR, et al. 2000. Conservation tillage initiatives in California. In: Proc of Conservation Tillage 2000: Conservation Tillage Success Stories from around the US, Feb 10-11, Davis, CA. UC Davis. 83 p.

Rask N, Triplett GB, van Doren DM. 1967. A cost analysis of no-tillage corn. Ohio Report 52(1):14.

Torgerson D, Duncan J, Dorgan A. 1987. Energy in US Agriculture. USDA Natural Resources Economic Division, Washington, DC. 8 p.

Towery D. 1998. Conservation tillage report "troubling" for US agriculture. Conservation Technology Information Center news release; Nov. 4, 1998. http://www.ctic.purdue .edu/Core4/CT/ctsurvey/AgTroubling.html

Uri ND. 1999. Energy and the use of conservation tillage in US agriculture. J Energy Policy 27:299-306. 